\title{
DIREKTIIVSED KÕNEAKTID EELKOOLIEALISTELE LASTELE SUUNATUD KÕNES, NENDE SEOTUS LAPSEVANEMA HARIDUSTASEMEGA JA MÕJU LAPSE SÕNAVARALE
}

\author{
ANDRA KÜTT
}

\begin{abstract}
Annotatsioon. Artikli eesmärk on anda ülevaade direktiividest eesti keelt emakeelena omandavatele kuueaastastele lastele suunatud kõnes. Täpsemalt on vaatluse all, millise otsesuse-kaudsuse astmega direktiive kasutatakse lastele suunatud spontaanses kõnes, kas ja kuidas on seotud direktiivide hulk ja liigid (st ka direktiivide kognitiivne keerukus) vanema haridustasemega ning kas direktiivsus on lapse sõnavara ulatust pärssiv tegur. Direktiivid on jagatud pragmaatiliselt eri tüüpideks: otsesteks ja kaudseteks käskudeks, keeldudeks, kõneleja soovitud tegevuse väljenduseks, palveteks, kaudset keeldu väljendavateks las-konstruktsioonideks, soovideks, soovitusteks, julgustuseks, ettepanekuteks, hoiakuteks, küsimusteks ja kultuurinormi edastuseks. Uurimismaterjal hõlmab üheksa tunni jagu spontaanse kõne lindistusi. Kokku on analüüsitud kuut peret: kolme peret, kus emal on kõrgharidus, ja kolme peret, kus emal on keskharidus. Lastele suunatud direktiivide arv varieerus pooleteisetunnistes vestlustes 46 direktiivist 130 direktiivini. Analüüsist ilmneb, et vanema hariduse ja direktiivide kasutuse vahel on otsene seos. Kõrgharidusega vanemate kõnes on keskmiselt kaks korda vähem direktiivseid lausungeid kui keskharidusega emadel. Seejuures iseloomustab kõrgharidusega vanemate kõnet kaudsete käskude kasutus, kuid direktiivide hulga ja tüüpide ning lapse sõnavara mitmekesisuse vahel ei ilmnenud otsest seost. Uurimistulemused näitavad direktiivsuse pärssivat mõju individuaalsel tasandil mida enam direktiive esineb vanema kõnes, seda väiksem on lapse sõnavara.
\end{abstract}

Võtmesõnad: esimese keele omandamine, lapsele suunatud kõne, sotsiolingvistika, direktiivid, sõnavara 


\section{Sissejuhatus}

Direktiivi mõistet on keeleteaduses mitmeti avatud (vt nt Ervin-Tripp 1976: 29; Curl, Drew 2008: 12; Hill 2009: 165; Tomasello 2010: 84; Stephany jt 2013: 11), kuid enamik uurimusi lähtub vähemal või suuremal määral John Searle'i kõneaktiteooriast (Searle 1979: 5, 11), kus direktiivi on käsitletud ülemmõistena, mis hõlmab soovi, käsku, käsklust, küsimust, anumist, palvet jm. Direktiiviks on loetud sel juhul igasugune kõneakt, mille eesmärk on kõneleja soov panna vestluspartner midagi tegema.

Direktiivide hulka lastele suunatud kõnes ehk laiemalt lapse kasvukeskkonnas on peetud laste kõne arengu mõjutajaks (vt nt Tomasello, Farrar 1986; Im-Bolter jt 2013). Kasvukeskkonna ja keelelise arengu seoste kohta on Eestis vähe teada ning ka maailmas on sellealased uuringud üsna uued. Arengupsühholoogia ${ }^{1}$ valdkonnas on Eestis mõnevõrra uuritud koduse kasvukeskkonna mõju keelele (Tulviste 2001, 2003, 2007; Laan 2006; Tammemäe 2008; Kaljumäe 2010; Urm 2012; Urm, Tulviste 2016). Uuritud on Eesti emade suhtlusstiili (Tulviste jt 2004) ning võrreldud tulemusi Soome, Rootsi ja Ameerika emade keelekasutusega (Tulviste 2001, 2007; Tulviste jt 2003). Neist uuringutest on selgunud, et Eesti emad paistavad silma direktiivse suhtlemisstiili poolest: lapsega ei räägita mitte suhtlemiseks, vaid tema tegevuse kontrollimiseks ja suunamiseks ${ }^{2}$.

1 Varasemad tööd sõnavara ja keskkonna mõju kohta põhinevad eelkõige MacArthur Batesi suhtlemistestidel. Reynelli kõne arengu skaalade kõne mõistmise osa ja Soome päritolu HYKSi testi on oma doktoriväitekirja aluseks olevates uuringutes kasutanud Tiiu Tammemäe (2008). Paljudes neis testides lastakse vanematel lapse sõnu ise kirja panna, kuid selline meetod võib anda tulemusi, mis erinevad paljuski spontaanses suhtlussituatsioonis saadutest. Näiteks on leitud, et madalama haridustasemega vanemate täidetud testid lapse kõneoskuse kohta ei kajasta tegelikku taset sedavõrd adekvaatselt kui kõrgema haridustasemega vanemate täidetud testid (vt nt Goldfield, Reznick 1990).

2 Helen Kõrgesaare (2014) ja siinkirjutaja (Kütt 2015) uurimistulemused paigutavad eesti hoidjakeele võrdlemisi vähedirektiivsete hulka: kõikidest vanemate kõne lausungitest moodustavad direktiivid vastavalt 13,9\% (Kõrgesaar) ja 5,85\% (Kütt). Helen Siska (2013) on vaadelnud käskiva kõneviisi kasutamist lapse ja ema suhtluses perioodil, mil laps on vanuses 1;7-3;2, ning leidnud, et lapsele suunatud kõnes on imperatiivsed väljendid aga võrdlemisi sagedased. Seevastu psühholingvistika valdkonna uurimuse (Tulviste jt 2004) järgi moodustavad 70\% kõikidest eesti vanemate lausungitest just direktiivid. 
Direktiive ja keeleomandamist käsitlevaid uurimusi on aga eesti keele kohta vaid üksikuid (Kütt 2015; Kütt, Argus 2017).

Teiste keelte puhul on vaadeldud vanemate haridustaseme ja direktiivsuse seoseid (vt nt Rowe 2008, Leech jt 2013). Muu hulgas on direktiivikasutuse erinevusi täheldatud ka kõrgema ja madalama sotsiaal-majandusliku staatusega vanemate kõnes. Chierika Okugu (2015) toob esile direktiivsuse ja sotsiaal-majandusliku staatuse seose ning avab sotsiaal-majandusliku staatust ühe komponendi, täpsemalt vanema haridustaseme kaudu. Tema uurimistulemused näitavad, et kõrgema ja madalama sotsiaal-majandusliku staatusega vanemate kõne erinevad direktiivikasutuse poolest märkimisväärselt: nii Ameerika kui ka Aafrika madalama sotsiaal-majandusliku staatusega vanemad kasutavad oma lastele suunatud kõnes oluliselt enam direktiive kui keskmise ja kõrgema sotsiaal-majandusliku staatusega vanemad $(i b$.). Seejuures ei ole siinkirjutaja andmetel lapsele suunatud erineva otsesuse-kaudsusega direktiivide kasutuse seos vanema haridustasemega varasemate uurimuste keskmes olnud. Siinne uurimus on ka esmane katse analüüsida vanemate direktiivide ja laste kasvukeskkonna seost eesti keele andmete põhjal ning vaadelda, milline on direktiivsuse mõju lapse sõnavarale. Erineva kasvukeskkonna mõistet avatakse vanema hariduse kaudu ning vaatluse all on kaks haridusrühma: kõrghariduse ja keskharidusega emad.

Uurimustes tavatsetakse sotsiaal-majandusliku staatuse ${ }^{3}$ mõistet defineerida sageli mitme indikaatori kaudu (nt sissetulek, haridustase ja tööalane prestiiž). Sellistes hiljutistes töödes domineerib arvamus, et isegi kui liitindeksil (nt haridustaseme mõju sissetulekule ${ }^{4}$ ) on väärtus, tuleks siiski uurida ka komponentide mõju eraldi (Bornstein jt 2003; Willms, 2003). Seejuures on haridustaset seostatud kõige enam kõne loomu ja stiiliga, mis mõjutavad otseselt lapse sõnavara arengut (Hoff 2003, 2006). Eeldusel et haridustase mõjutab kõne loomu, võiks kõrgharitud vanema kõne olla seega keerukam, st sisaldada kognitiivselt ja grammatiliselt keerukamaid konstruktsioone, sealhulgas eri direktiivitüüpe. Kitsamalt

3 Vt arutlust mõistete sotsiaal-majanduslik staatus, sotsiaalne klass ja erinev kasvukeskkond üle Kütt 2015; Kütt, Argus 2017.

$4 \mathrm{Ka}$ Eesti kontekstis on leitud, et haridustase on sissetulekuga positiivses korrelatsioonis. Olukord on aga maakonniti erinev, mistõttu tuleks siinkirjutaja hinnangul arvestada haridustaseme ja sissetuleku seoste analüüsimisel ka muid kasvukeskkonna tegureid, nt elukohta (vt Leping 2015). 
võiks direktiivide analüüs aidata avada vanema kõne üldist olemust ning selle mõju lapse sõnavarale ja keelele laiemalt.

Töid, milles käsitletakse direktiivseid kõneakte ${ }^{5}$, on eesti keele kontekstis vähe. Helle Metslang (2004) on uurinud argikõne direktiivsuse väljendamise võimalusi, esitades direktiivide moodustamise keelelised vahendid. Helena Teemets (2012) on samuti vaadelnud lähemalt direktiive eesti argivestlustes, pöörates tähelepanu kitsamalt nende vormile ja funktsioonile. Direktiivide vormile, täpsemalt polüfunktsionaalsetele küsilausetele ehk lausungitele, mille abil tehakse samal ajal mitut suhtlustegevust, on keskendunud Kirsi Laanesoo (2018), uurides igapäevases suulises suhtluses esinevaid küsilauseid, mis ei ole põhifunktsioonilt küsimused, vaid toimivad muu hulgas direktiivsete lausungitena. Kitsamalt on direktiivide seost tingiva kõneviisiga vaadelnud Karl ja Renate Pajusalu (2004: 265, 268), leides, et tingiva kõneviisi abil väljendatakse sageli soove ja palveid (nt Kas te võiksite mulle ulatada ...?), mis on aga tüüpilised direktiivid, sest kõneleja eesmärk on panna kuulaja midagi tegema. Autorite huvikeskmes ei olnud erineva tugevusastmega palved, seetõttu on ka käsud, anumine jm seda tüüpi suhtlustegevused liigitatud palvete hulka.

Direktiividele keskenduvaid hoidjakeelealaseid uurimusi leidub vaid üksikuid. Andriela Rääbis on juhtumiuuringu abil vaadelnud, kuidas isa kasutab direktiive suhtluses oma 5-aastase tütrega. Direktiivid struktureerivad vestluses dialoogi: isa (harvem laps) annab korralduse/juhise järgmiseks tegevuseks või järjestab edasised tegevused. Uurimuses tuleb esile ka lapsevanema ja lapse ebasümmeetria. Nimelt on lapsele suunatud kõnes märgatavalt enam direktiive kui lapse enda kõnes. (Rääbis 2012)

Pikiuuringuga on Helen Kõrgesaar (2014) analüüsinud 9-14-aastaste laste ema ja isa kõnes ${ }^{6}$ esinenud ning lapsele suunatud direktiive. Tulemustest ilmneb, et lastele suunatud kõne funktsionaalne jaotus on mõlema vanema puhul üsnagi sarnane ning vanemad kasutavad direktiive peaaegu võrdsel määral (direktiivsete lausungite osakaal jäi isa kõnes 17\% ja ema

5 Eesti keele grammatika direktiivikäsitlust vt EKG II, lk 174-176. „Eesti keele süntaksis“ (2017) esitatakse peamiselt kirjaliku eesti keele lauseehituse deskriptiivne uurimuslik tervikkäsitlus.

${ }^{6}$ Siinses uurimuses analüüsitakse ema kõnet, sest nagu väidab Erika Hoff (2006), mõjutab sotsiaal-majanduslik tase laste kõne arengut eelkõige ema kõne kaudu. Esimese keele omandamise uurimused ja Eesti lapsele suunatud kõne uurimused põhinevad samuti peaasjalikult emade keelekasutusel. 
kõnes 19\% juurde). Kõrgesaare uurimistulemused osutavad, et kuigi direktiivide hulk täiskasvanu kõnes aja jooksul üldiselt väheneb, moodustavad otsesed käsud, mis on 9-14-aastase lapsega suheldes nii ema kui ka isa kõnes levinuimad, enam kui poole vestluses kasutatavatest direktiividest. Seejuures näitas direktiivikasutuse suhtluskorrapõhine vaatlus, et kõige enam otseseid käske esines neis suhtlussituatsioonides, kus lapsel oli õppija või abistaja roll, täiskasvanul aga õpetaja-instrueerija roll. Vähem otseseid käske leidus nendes situatsioonides, kus tehti küll midagi koos, kuid üksnes lapse palvel või olukordades, kus sihipärane tegevus puudus. Käsu intensiivsus sõltub Kõrgesaare hinnangul ka sellest, kui tähtis on suunata last mingit tegevust tegema või kui ohtlik tema tegevus parasjagu on. Muid direktiivide liike esineb lapsele suunatud kõnes vähem. Ema kõnes järgnesid otsestele käskudele keelud, kõneleja soovitud tegevuse väljendamise viisid ja soovitused. Palveid ja hoiatusi esineb mõlema vanema kõnes harva. (Kõrgesaar 2014: 168-170)

Siinkirjutaja on varasemas töös (Kütt $2015^{7}$ ) uurinud erineva sotsiolingvistilise kasvukeskkonna mõju eelkooliealise lapse sõnavarale ning ühe keelelise näitajana vaadanud ka direktiivide ${ }^{8}$ ja julgustuse esinemist lastele suunatud kõnes, täpsemalt haridustaseme ja elukoha seost direktiivsusega. Selgus, et linnapiirkonna emad on lastega kõneledes märksa direktiivsemad kui maapiirkonna emad, kelle kõnes leidus seevastu enam julgustusi. Nii maa- kui ka linnakeskkonna vanemate seas olid direktiivsemad keskharidusega vanemad. Maapiirkonna lastel oli aga rikkam sõnavara, mis võib siinkirjutaja arvates olla seotud neile suunatud kõnes esineva väiksema direktiivsusmääraga. (Kütt 2015: 54)

Direktiivid on kõne loomulik osa ja need on lapsevanemale abiks nii lapse tegevuse juhtimisel, suunamisel kui ka tema õpetamisel. Need on igapäevasuhtluses olulised kõneaktid ning seetõttu omandavad lapsed

${ }^{7}$ Uuringus osales kaheksa peret. Perede valimisel lähtuti kolmest parameetrist: ema haridusest, elukohast (maa- ja linnakeskkond) ning lapse käimisest või mittekäimisest lasteaias. Hariduse alusel eristus kaks rühma: kõrgharidusega vanemad ja kõrghariduseta vanemad (nt need, kel on kesk-, keskeri-, kutse- või põhikooliharidus). Seejärel täpsustati ema hariduse laadi ja suunda (kõrgharidus või rakenduskõrgharidus, humanitaar- või reaalala). Samuti analüüsiti mõlema parameetri (kõrgharidusega ja kõrghariduseta ning linna- ja maakeskkond) puhul nii lapsi, kes käivad lasteaias, kui ka lapsi, kes on peamiselt kas ema, vanavanemate või hoidjaga kodus.

${ }^{8}$ Uurimuses ei vaadeldud eri direktiivitüüpide mõju lapse sõnavarale. 
keeliti eri tüüpi direktiivsed väljendusvahendid varakult (Aikenvald 2010: 326; Stephany, Voeikova 2015). Tegijakeskset modaalsust eesti keelt emakeelena omandamisel on kahe ükskeelse lapse ja emade spontaanse kõne lindistustele tuginedes uurinud Reili Argus ${ }^{9}$. Täpsemalt on tema uurimuses vaatluse all, milliseid pragmaatilisi käsutüüpe ja keelelisi vahendeid direktiivide moodustamiseks kasutatakse. Arguse uurimuse järgi domineerivad lastele suunatud kõnes otsesed käsud, keelud ja kõneleja soovitud seisundit väljendavad direktiivid, kaudsete käskude osakaal on direktiivide hulgas aga väga väike. Otseses käsus kasutatav verbivorm on grammatiliselt üks lihtsaimaid vorme eesti keele verbi paradigmas ja see ilmub esimesena ka laste kõnesse (nt Anna!, Oota!). Peale grammatilise lihtsuse toetavad selle vormi omandamist pragmaatiline vajadus ning lapse ja vanema lähedane suhe, mis soodustab selliste kõnevormelite kasutamist registrina (vt ka Ervin-Tripp 1976: 29; Craven, Potter 2010: 420) ${ }^{10}$. Käsud, mis väljendavad kõneleja soovitud tegevust/seisundit ja sotsiaalseid norme, ilmuvad lapse kõnesse kõige hiljem. Seega võiksid autori hinnangul eri tüüpi direktiivide omandamisel olulised olla nende sagedus lastele suunatud kõnes, grammatiline lihtsus-keerukus ning ka abstraktsus ehk see, kui selgelt on käsus väljendatud käsu adressaat. Uurimistulemustest ilmnebki, et kuigi lastele suunatud kõnes on arvukalt eri tüüpi käske, puuduvad mõned neist laste kõnest. Nende hulka kuuluvad eelkõige nii kognitiivselt kui ka grammatilisemalt raskemad, nt kohustused (nt On vaja lugeda), kaudsed keelud (nt Seda ei tohiks võtta), hoiatused (nt Kui sa seda ära ei võta sealt, kukub see alla), sotsiaalseid norme väljendavad käsud (nt Enne sööki pestakse käsi), ehk need tüübid, mis on lastele suunatud kõnes harvad. (Argus, ilmumas).

Grammatika ja pragmaatika seost direktiivide omandamisega on tšehhi keele hiljutise uuringu põhjal kirjeldanud Pavla Chejnová (2015). Tema sõnul saavad direktiivide omandamine ja kasutamine areneda välja

9 Arguse järgi omandavad eesti lapsed eri tüüpi direktiive pigem pideva protsessina kui selgete eristuvate perioodide kaupa, alustades kognitiivselt ja grammatiliselt vähem keerukate konstruktsioonidega. Mitmes varasemas uurimuses (vt nt Huls, van Wijk 2012) on direktiivide omandamist käsitledes jõutud samuti järelduseni, et direktiivide arengus ei ole selgelt eristuvaid perioode ning pigem on tegu lineaarselt vaadeldava protsessiga.

${ }^{10}$ Vestlusanalüüsil põhineva käsituse kohaselt ei ole eri vormivariandid seotud mitte viisakuse ega otseselt võimuga, vaid partneritevaheliste suhete, ootuste ja kontekstidega, milles need esitatakse. 
vaid siis, kui lapsel ei ole n-ö grammatilisi piiranguid ${ }^{11}$ (vt ka Clark 2003; Tomasello 2005; Slančová 2008). Gerlind Grosse'i jt (2010) katse 21 kuu vanuste lastega näitas, et juba enne kaheaastaseks saamist mõistavad lapsed suhtluses kehtivat koostööpõhimõtet, täpsemalt käskude loogikat. See tähendab, et eri tüüpi direktiivide kasutamine ka lastele suunatud kõnes viitab suhtluse keerukamaks muutumisele: keeleliselt võimekamale ja vanemale lapsele saab käske edasi anda kaudselt - soovi, palve, üldise kultuurinormi või hoiatusena (Kõrgesaar 2016: 47). Seega võiks siinses uurimuses kasutatud valimi vanuse järgi eeldada, et lastele suunatakse ka kognitiivselt keerukamaid käske ja nad on võimelised neid mõistma.

Olgugi et direktiividel on kultuurinormi edastusena (nt Ruumi sisenemisel tervitatakse) täita oluline roll lapse sotsialiseerumises ning keeleliselt rikka direktiivse väljendiga saab kaudselt kaasa aidata uute sõnade õppimisele ja sõnavara arengule, ilmneb sellealasest kirjandusest (vt nt Nelson 1973; Tomasello, Todd 1983; Harris jt 1986; Akhtar jt 1991; Bornstein jt 1999; Paavola-Ruotsalainen jt 2017) enamasti siiski, et direktiivsus avaldab eri vanuses ja eas laste keelelisele arengule eri keeletasanditel negatiivset mõju. Direktiive on peetud eelkõige kõneaktiks, mis ootab primaarsena tegevust, millega võib, aga ei pruugi kaasneda verbaalne reaktsioon. Barry Prizant ja Elaine C. Meyer (1993) seovad vanema direktiivsuse otseselt lapse passiivsuse ning vähenenud initsiatiiviga ise suhtlust alustada. Lapsele suunatud kõnes esinevat suurt direktiivsust on käsitletud ka lapse akadeemilist edukust ennustava faktorina - ema suurem direktiivsus on korrelatsioonis lapse halvemate koolihinnetega, saavutus- ja intelligentsustestide tulemustega (vt nt Frank Masur, Turner 2001). Mitmes uurimuses osutatakse seejuures madalama haridustasemega vanemate suuremale direktiivsusele suhtluses lastega. Nii näitavad Betty

${ }^{11}$ Pragmaatilise kompetentsi väljakujunemine on huvitanud keeleteadlasi juba pikka aega. Elizabeth Batesi (1976) järgi võib direktiivide kasutamisel eristada kolme arengufaasi: a) 4. eluaastani ei leidu tavaliselt laste kõnes kaudseid käske, enamasti esinevad kõnes otsesed käsud või soovid; b) 5.-6. eluaastaks on lapsed võimelised moodustama peaaegu kõiki süntaktiliselt võimalikke direktiivitüüpe, kuid nad ei suuda alati arvestada konteksti ja moodustada sellele vastavat direktiivi (nt kaudseid käske); c) 7. eluaastaks on laps omandanud direktiivi moodustamise pragmaatilised ja kommunikatiivsed oskused. Elaine S. Andersen (1990) väidab koguni, et lapsed vanuses 4;7-6;10 suudavad käsu moodustamisel arvestada kaasvestleja positsiooni ja seega viisakusastet - kaudseid käske moodustati autoriteetsema adressaadi puhul. 
Harti ja Todd Risley mahuka pikiuuringu ${ }^{12}$ (2003) tulemused, et sotsiaalmajandusliku staatuse mõju laste keelekeskkonnale ja keele arengule on väga tugev ning erinevused rühmade vahel on suured. Kõige madalama tasandi sotsiaal-majanduslikku rühma kuuluv laps kuuleb üle kahe korra rohkem keelde kui julgustavaid lauseid ning aastas enam kui 30000 keeldu rohkem kui kõige kõrgema tasandi rühma kuuluv laps. Erika HoffGinsbergi (1998) uuringust selgus, et kõrgharidusega emad räägivad oma lastega rohkem ja kasutavad ka rikkalikumat sõnavara, samuti reageerivad nad lapse kõnele sagedamini, kasutavad vähem direktiivseid otseseid käsklusi ning küsivad lapselt enam küsimusi kui keskharidusega emad, kelle lapsed kuulevad vähem kõnet, kuid seevastu oluliselt enam keelde.

Julian M. Pine (1992) seab direktiivide negatiivse mõju kuvandi aga kahtluse alla, väites, et lapsevanema kasvatuspraktika või kultuuritaust ja sellest tingitud kõrgem direktiivsusmäär ei ole alati negatiivses korrelatsioonis lapse kõne arenguga (vt ka Ellis, Wells 1980; Barnes jt 1983). Ka Nameera Akhtar jt (1991) toovad esile direktiivsuse otsese kasu ja seotuse sõnavara arenguga, eristades lapse tähelepanu juhtivat (leading) ning jagatud tähelepanust johtuvat ja seda järgivat (follow-prescriptives) direktiivi, millest viimane on sõnavara arenguga positiivses seoses ning kinnitab ka vanema uskumust, et laps võib olla võrdväärne vestluspartner.

Uurimuse üldteoreetiline lähtekoht on kasutuspõhise keeleomandamise teooria ${ }^{13}$, mille järgi mõjutab keele omandamist eelkõige lapse ja täiskasvanu suhtlustasand ${ }^{14}$, st kas see pakub lapsele keeleliseks arenguks vajalikku (Tomasello 2003: 21-23). Eelkirjeldatud uurimistulemustest ja -problemaatikast tulenevad siinse uurimuse hüpoteesid.

${ }^{12}$ Uuringus vaadeldi ligi kaks ja pool aastat 42 peret. Võrreldes eri sotsiaal-majanduslike rühmade peresid, ilmnes kõnekas erinevus lapsele suunatud kõne mahus: kõige kõrgema tasandi sotsiaal-majanduslikku rühma kuulunud laps oli 4-aastaseks saades kuulnud ligi 45 miljonit sõna, keskmisesse rühma kuulunud laps 26 miljonit sõna ja kõige madalama tasandi rühma kuulunud laps 13 miljonit sõna. See teeb kõige kõrgema ja madalama tasandi erinevuseks ligi 30 miljonit sõna. (Hart, Risley 2003: 7-9)

${ }^{13}$ Vt ka Vihman 2018.

${ }^{14}$ Keeleomandamist on peetud eelkõige sisendkeele sagedustel ja eelistustel põhinevaks protsessiks, mis eeldab keelemoodulitevahelist koostööd (vt Argus 2008: 42). Kasutuspõhise keeleomandamise teooria juures on oluline rõhutada, et laps omandab selle keele, mida tema keelekeskkonnas räägitakse, mistõttu lapsele suunatud kõne iseloom, sh direktiivide esinemine lapsele suunatud kõnes, kas soosib või pärsib tema keelelist arengut (vt nt Hoff 2003; Huttenlocher jt 2010; Rowe 2012). 
1. Kõrgema ja madalama haridustasemega vanemad kasutavad lapsele suunatud kõnes erineval hulgal direktiive.

2. Lastele suunatud verbaalse sisendi erinevus, sh direktiivide erinev määr, tingib laste kõnes nii individuaalseid kui ka rühmaomaseid erinevusi.

3. Lapsele suunatud direktiivne kõne eristub kõne hulga, sõnavara mitmekesisuse ja väljendite keskmise pikkuse poolest.

4. Direktiivsemate vanemate lastel on väiksem kõne hulk ja vaesem sõnavara.

5. Lapse sõnavara suurusele avaldab mõju mitte ainult direktiivide üldine hulk, vaid ka nende laad ehk direktiivi intensiivsus (otsesus-kaudsus).

6. Kõrgemalt haritud vanemate kõnes leidub enam kaudseid käske, madalamalt haritud vanemate kõnes otseseid käske-keelde.

\section{Uurimismeetod ja andmestik}

Analüüs põhineb kuue pere - kolme kõrgharidusega ema ning kolme kesk(eri)haridusega ema ja lapse - spontaanse kõne lindistustel. Uurimismaterjal hõlmab üheksa tunni jagu lindistusi, igat peret on võrdselt lindistatud poolteist tundi. Kõikide lindistuste juures on viibinud siinkirjutaja $^{15}$. Kuna erinev suhtlusolukord võib direktiivide hulgas ja laadis erinevusi tekitada (vt nt Kõrgesaar 2015: 166), olid uurimuse jaoks valitud sarnast tüüpi suhtlussituatsioonid. Lindistatud kõne esindab argisituatsioonide (nt üheskoos lauamängu mängimine, meisterdamine, raamatu vaatamine) spontaanseid dialooge. Vaatlusalused dialoogid transkribeeriti, kasutades CHILDES-süsteemi (MacWhinney 2000), ning transkriptsioone analüüsiti CLAN-programmiga (MacWhinney 1991).

Transkribeeritud tekstist on välja korjatud kõik ema kõnes esinevad direktiivsed lausungid. Kaks või enam direktiivi, mis sisaldusid ühes

${ }^{15}$ Kasutatud on uurimismaterjali, mille põhjal loodud korpus võimaldab teha eesti keelt emakeelena omandavate 6-7-aastaste laste sotsiolingvistilisi uuringuid. Materjal on kogutud kindlate sotsiolingvistiliste kriteeriumite järgi, arvestades järgmisi algtingimusi: peres on kaks last; lindistatakse vanema lapse ehk esimese lapse spontaanset kõnet emaga; lapsel ja vanemal ei ole vaimset puuet; pere ei ole kakskeelne. Keelematerjali on kogunud ja transkribeerinud Andra Kütt. 
lausungis (nt Kuula ja pane see asi käest!), on arvestatud eraldi direktiividena. Direktiivide esimene jaotus on pragmaatiline ehk põhineb direktiivi otsesusel-kaudsusel. Teisel jaotustasandil on vaadeldud direktiivide tüüpe, mille järjestamisel on silmas peetud käsu intensiivsust, alustades tugevamast direktiivist. Käskude liigitamisel on osaliselt tuginetud Kõrgesaare uurimuses kasutatud direktiivide kombineeritud jaotusele (vt Kõrgesaar 2014: 163-164). Käsud on jaotatud Susan Ervin-Tripi (1976) eeskujul otsesteks käskudeks (direct directives) ja kaudseteks käskudeks (indirect directives). Ursula Stephany jt (2013: 11) käsitlusest on pärit keelud (prohibitions), kõneleja soovitud tegevuse väljendamise viisid, mis on seotud kolmanda osalisega (statement of desired action), kultuurinormi edastus (statements of social rules), hoiatused/vihjed (warnings/hints) ja ettepanekud (proposals). Palved (requests), soovid (wishes) ja soovitused (suggestions), mis esinevad ühe või teise nimetuse all mitme autori käsitluses, on arvestatud eri kategooriateks. Eraldi direktiivitüüpidena on vaadeldud küsimuse vormis direktiive (questions), las-konstruktsioone (description of a situation to be pertained) ja julgustust (encouragements). Materjali liigitusalus on esitatud tabelis 1 (direktiive kirjeldatakse konstrueeritud näidete varal).

Tabel 1. Lapsele suunatud kõnes esinenud direktiivide jaotus materjali liigitusalusena

\begin{tabular}{|c|c|}
\hline \multirow{2}{*}{$\begin{array}{l}\text { Otsesed } \\
\text { käsud }\end{array}$} & Käsk (Tule siia!; Räägi korralikult!) \\
\hline & Keeld (Ära puutu!; Ei võta kommi!) \\
\hline \multirow{10}{*}{$\begin{array}{c}\text { Kaudsed } \\
\text { käsud }\end{array}$} & $\begin{array}{l}\text { Kõneleja soovitud tegevuse väljendus (Teeme siis niimoodi, } \\
\text { et paneme need asjad sinna.) }\end{array}$ \\
\hline & Ettepanek (Hakkame hoopis sü̈̈a tegema.) \\
\hline & Palve (Palun aita venda.) \\
\hline & Las-konstruktsioon (Las need asjad olla seal!) \\
\hline & Soov (Ma soovin/sooviksin seda.) \\
\hline & Soovitus (Sa peaksid õppima!; Sa ei pea kõike ära sööma!) \\
\hline & Julgustus (Proovi kirjutada!) \\
\hline & Hoiatus, vihje (Kui sa selle sinna paned, siis kukub see maha.) \\
\hline & Küsimuse vormis direktiiv (Kas ma võin paluda su abi?) \\
\hline & $\begin{array}{l}\text { Kultuurinormi edastus (Ühekaupa räägitakse!; } \\
\text { Enne sööki pestakse käsi!) }\end{array}$ \\
\hline
\end{tabular}


Kõiki direktiivitüüpe iseloomustab vanema soov last midagi tegema panna. Direktiivide liigitamisel lähtuti eelkõige kontekstist ja situatsioonist, mitte niivõrd grammatikavahenditest. Otsene käsk võib põhineda nii kasutatud grammatikavahenditel, st imperatiivil, kui ka pragmaatilistel teguritel, nt tugevusastmel (nt on pragmaatiliselt väga otsene lause „Seda sa ei võta!“, kuigi imperatiivivormi seal ei ole). Seevastu osutus käsu adressaadile (kas verbivormi või käsu adressaadi väljendamisega) ei muuda direktiivi alati otseseks. Nii on liigitatud kaudseteks käskudeks näiteks soovitused, palved, ettepanekud, küsimused, kus käsu adressaat on määratud enamasti verbi pöördevormi kaudu, sealhulgas mitmuse esimese pöörde kaudu, nt õpime, kuigi sisuliselt on käsk suunatud lapsele. Käsku võidakse varjata pehmema väljendusviisiga, esitades selle palve, küsimuse, ettepaneku, vihje vm kujul. Nii on ka kultuurinormi edastamine kaudne direktiiv, mis kannab vanema soovi last õpetada, kuid mille eesmärk on alati lapse tegevuse juhtimine ning soovitud/keelatud tegevusele viitamine. Kultuurinormi edastav direktiiv on kognitiivselt lapse jaoks ka kõige keerukam, sest väljendatud ei ole ei käsu adressaati ega käsu andjat. Julgustus, mis võib muu hulgas õhutada last suhtlema (Räägi!), toimib pragmaatiliselt samuti direktiivina, suunates lapse käitumist, ning see on liigitatud kaudseks käsuks.

Laste kõnes on analüüsitud kõne hulka (sõnedes) ja sõnavara mitmekesisust (lekseemides) ning väljendi keskmist pikkust. Samu keelelisi näitajaid on vaadatud ka lastele suunatud kõnes, et näha, kas direktiivset kõnet iseloomustavad ka erinevused sõnavara ja lausungi tasandil. Lapsele suunatud direktiivide ja nende kognitiivse keerukuse analüüs annab vastuse küsimusele, kas ja kuidas, st täpsemalt mis tüüpi direktiivid on seotud lapse sõnavaraga.

\section{Lapsele suunatud direktiivide hulga seos vanema kõne ja haridustasemega}

\subsection{Direktiivse kõne hulk ja selle eriomased jooned}

Lastele suunatud direktiivide arv jääb pooleteisetunnistes vestlustes 46 direktiivi (KeskH $\left.2^{16}\right)$ ja 130 direktiivi (KeskH 1) vahele. Seega on peaaegu

${ }^{16}$ Pered on siin ja edaspidi tähistatud haridustaseme järgi järgmiste koodidega: KõrgH 1, KõrgH 2, KõrgH 3; KeskH 1, KeskH 2, KeskH 3. 
kolmekordne vahe selles, kui palju direktiive kuuleb laps ühes sama pikas vestluses. Direktiivsete lausungite osakaal varieerub vestlustes samuti suuresti, ulatudes 6,71\%-st (KõrgH 2) 29,67\%-ni (KeskH 1). Kõige enam direktiive kasutanud emal moodustavad käsud-keelud veidi vähem kui kolmandiku kõikidest tema lapsele suunatud lausungitest. Ülevaade lastele suunatud direktiivide ja direktiivsete lausungite hulgast ning direktiivsete lausungite osakaalust kõikidest lausungitest on esitatud tabelis 2 .

Tabel 2. Ema kõne üldülevaade

\begin{tabular}{|l|c|c|c|c|}
\hline \multicolumn{1}{|c|}{ Pere } & $\begin{array}{c}\text { Ema } \\
\text { lausungite } \\
\text { hulk }\end{array}$ & $\begin{array}{c}\text { Lapsele } \\
\text { suunatud } \\
\text { direktiivide } \\
\text { hulk }\end{array}$ & $\begin{array}{c}\text { Direktiivsete } \\
\text { lausungite } \\
\text { hulk }\end{array}$ & $\begin{array}{c}\text { Direktiivsete } \\
\text { lausungite } \\
\text { osakaal kõikidest } \\
\text { lausungitest }\end{array}$ \\
\hline KõrgH 1 & 842 & 115 & 102 & $12,11 \%$ \\
\hline KõrgH 2 & 715 & 50 & 48 & $\mathbf{6 , 7 1 \%}$ \\
\hline KõrgH 3 & 683 & 54 & 50 & $7,32 \%$ \\
\hline Keskmine & $\mathbf{7 4 6 , 6 7}$ & 73 & 66,67 & \\
\hline KeskH 1 & 401 & 130 & 119 & $\mathbf{2 9 , 6 7 \%}$ \\
\hline KeskH 2 & 516 & 46 & 42 & $8,14 \%$ \\
\hline KeskH 3 & 537 & 77 & 71 & $13,22 \%$ \\
\hline Keskmine & $\mathbf{4 8 4 , 6 7}$ & 84,33 & 77,33 & \\
\hline
\end{tabular}

Lausungite arv pooleteisetunnises vestluses erineb üle kahe korra. Nii on KõrgH 1 ema kõnes 842 lausungit ja KeskH 1 ema kõnes 401 lausungit, mis on suunatud lapsele. Kogu materjali põhjal, st vaatamata korrelatsiooni haridusrühma sees, ei leidu otsest seost, mis osutaks, et mida direktiivsem on ema, seda vähem suunab ta lapsele lausungeid. Küll aga on näha, et kõige direktiivsem ema (KeskH 1) suunab oma lapsele ka kõige vähem lausungeid. Samuti ilmneb uurimistulemustest, et kõrgharidusega emad suunavad lapsele vestluses keskmiselt 746,67 lausungit ja keskharidusega emad 484,67 lausungit. Et analüüsida direktiivsust kui vanema kõnet iseloomustavat tegurit, on tabelis 3 esitatud emade kõne hulk, sõnavara mitmekesisus ja väljendi keskmine pikkus. 
Tabel 3. Direktiivsusmäära seos ema lausungi keskmise pikkuse, sõnavara hulga ja mitmekesisusega lapsele suunatud kõnes

\begin{tabular}{|l|c|c|c|c|}
\hline \multicolumn{1}{|c|}{ Pere } & $\begin{array}{c}\text { Direktiivsete } \\
\text { lausungite } \\
\text { osakaal kõikidest } \\
\text { lausungitest }\end{array}$ & $\begin{array}{c}\text { Ema } \\
\text { kõne hulk } \\
\text { sõnedes }\end{array}$ & $\begin{array}{c}\text { Ema } \\
\text { sonnavara } \\
\text { mitmekesisus } \\
\text { lekseemides }\end{array}$ & $\begin{array}{c}\text { Ema } \\
\text { lausungite } \\
\text { keskmine } \\
\text { pikkus } \\
\text { sõnedes }\end{array}$ \\
\hline KõrgH 1 & $12,11 \%$ & 4740 & 706 & 5,51 \\
\hline KõrgH 2 & $\mathbf{6 , 7 1 \%}$ & 4437 & 750 & 6,11 \\
\hline KõrgH 3 & $7,32 \%$ & 4270 & 831 & 6,07 \\
\hline Keskmine & & 4482,33 & 762,33 & \\
\hline KeskH 1 & $\mathbf{2 9 , 6 7 \%}$ & 2041 & 362 & 4,93 \\
\hline KeskH 2 & $8,14 \%$ & 2567 & 601 & 4,88 \\
\hline KeskH 3 & $13,22 \%$ & 2683 & 580 & 4,90 \\
\hline Keskmine & & 2430,33 & 514,33 & \\
\hline
\end{tabular}

Lastele suunatud kõne kõige kõrgem direktiivsusmäär (KeskH 1) ei ole seotud mitte ainult lapsele suunatud lausungite kõige väiksema hulgaga, vaid ka ema kõnes sisalduvate sõnede kõige väiksema hulgaga: laps kuuleb vestluse jooksul 2041 sõnet, seega üle kahe korra vähem kui KõrgH 1 pere laps (4740 sõnet). Kõikide perede arvestuses ei esine aga negatiivset seost ema kõne direktiivsusmäära ja kõne hulga vahel.

Uurimistulemustest ilmneb seos kõige kõrgema direktiivsusmäära ja ema sõnavara mitmekesisuse vahel: kõige suurema direktiivide osakaaluga ema kõne sõnavara on kõikide emade võrdluses ligi kaks korda väiksem. Niisamuti on kõige vähem direktiivse ema kõne ligi kaks korda mitmekesisem kui kõige kõrgema direktiivsusmääraga ema kõne.

Eelkooliealistele lastele suunatud lausungid koosnevad 5-6 sõnest. Suuri erinevusi lausungi keskmises pikkuses perede lõikes ei ole. Kõige vähem direktiive kasutanud ema (KõrgH 2) lausungid on teiste emade võrdluses aga kõige pikemad (6,11 sõnet).

Seega, analüüsides lastele suunatud direktiivseid lausungeid kogu materjalis ehk vaatamata kahte haridusrühma eraldi, eristub üks ema, kelle kõne on kõige direktiivsem. Kõrge direktiivsusmäära korral oli kõnes vähem sõnesid ja lapsele suunatud lausungeid, samuti oli lausungi keskmine pikkus lühem ning sõnavara kasinam. 


\subsection{Lastele suunatud direktiivide seos vanema haridustasemega}

Võrreldes ema kõne hulka, mitmekesisust, väljendi keskmist pikkust ja väljendite arvu, ilmnesid selged erinevused haridusrühmade vahel. Kõrgema haridustasemega emad kasutavad ühes pooleteisetunnises vestluses lastega keskmiselt üle 2000 sõne rohkem (KõrgH - keskmiselt 4482,33 sõnet, KeskH - 2430,33 sõnet, vt tabel 2). Kõrgharidusega emade keel on mitmekesisem (KõrgH - keskmiselt 762,33 lekseemi, KeskH - 514,33 lekseemi). Igas vestluses on kõrgharidusega emade peredes suunatud lapsele rohkem lausungeid (KõrgH - keskmiselt 746,67 sõnet, KeskH 484,67 sõnet) ning nende väljendite pikkus on igas vestluses umbes ühe sõne võrra pikem (vt tabel 3).

Kõrge direktiivsusmäär on seotud lapsele suunatud väiksema kõnehulga, lausungite arvu, kasinama sõnavara ja väljendi väiksema keskmise pikkusega. Direktiivide erinev kasutusmäär on seejuures mõjutatud vanema haridustasemest. Joonis 1 annab ülevaate direktiivide osakaalust kahe haridusrühma sees.

Keskmine: KeskH 17,01\%

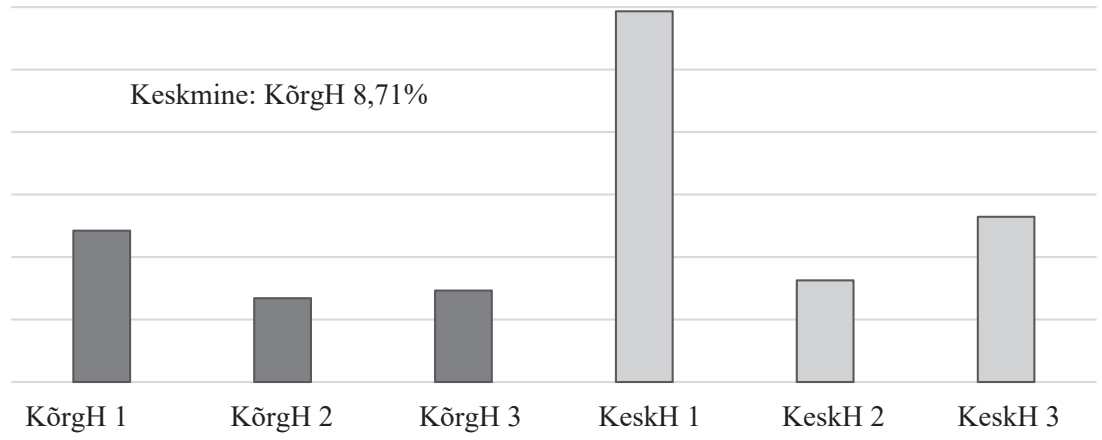

Joonis 1. Direktiivsete lausungite osakaal kõrgharidusega (KõrgH 1-3) ja keskharidusega (KeskH 1-3) peredes

Madalama haridustasemega peredes on direktiivsus suurem kui kõrgema haridustasemega peredes: keskharidusega emade kõnes ulatub direktiivsete lausungite hulk 8,14\%-st 29,67\%-ni, kõrgharidusega emade kõnes jääb direktiivide osakaal vastavalt vahemikku 6,71-12,11\%. Kõrgharidusega vanemate rühma sees eristub KõrgH 1 pere direktiivsete lausungite 
suurema hulga poolest ${ }^{17}$ (12,11\% direktiivseid lausungeid). Keskmiselt on kõrgharidusega vanemate direktiivsete lausungite osakaal 8,3\% väiksem kui keskharidusega emadel (KõrgH - 8,71\%, KeskH - 17,01\%).

Direktiivset kõnet iseloomustab seega lapsele suunatud kõne väiksem hulk, kasinam sõnavara ja lühemad lapsele suunatud lausungid. Direktiivide kasutus on aga otseselt seotud vanema haridustasemega: keskharidusega emad kasutavad lastega vesteldes enam direktiivseid lausungeid, kui seda teevad kõrgharidusega emad.

\section{Direktiivsus kui sõnavara kitsendav tegur}

Kahe haridusrühma vahel esineb erinevus nii ema kõne iseloomus kui ka direktiivide kasutusmääras. Tabelis 4 on kõrvutatud ema kõne andmeid laste omadega.

Tabel 4. Ema kõne andmed võrdluses lapse kõne andmetega

\begin{tabular}{|l|c|c|c|c|c|c|c|}
\hline \multicolumn{1}{|c|}{ Pere } & $\begin{array}{c}\text { Ema } \\
\text { lausun- } \\
\text { gite } \\
\text { arv } \\
\text { suunatud } \\
\text { direktiivsete } \\
\text { lausungite } \\
\text { osakaal kõiki- } \\
\text { dest lausun- } \\
\text { gitest }\end{array}$ & $\begin{array}{c}\text { Ema } \\
\text { kõne } \\
\text { hulk }\end{array}$ & $\begin{array}{c}\text { Lapse } \\
\text { lausun- } \\
\text { gite } \\
\text { arv }\end{array}$ & $\begin{array}{c}\text { Lapse } \\
\text { väljendite } \\
\text { keskmine } \\
\text { pikkus }\end{array}$ & $\begin{array}{c}\text { Lapse } \\
\text { kõne } \\
\text { hulk } \\
\text { sonnedes }\end{array}$ & $\begin{array}{c}\text { Lapse } \\
\text { sõnavara } \\
\text { mitme- } \\
\text { kesisus } \\
\text { leksee- } \\
\text { mides }\end{array}$ \\
\hline KõrgH 1 & 842 & $12,11 \%$ & 4740 & 658 & 4,26 & 2910 & 405 \\
\hline KõrgH 2 & 715 & $6,71 \%$ & 4437 & 471 & 4,38 & 2109 & 500 \\
\hline KõrgH 3 & 683 & $7,32 \%$ & 4270 & 469 & 3,85 & 1899 & 475 \\
\hline Keskmine & 746,7 & 8,71 & 4482 & 532,7 & 4,16 & 3276 & 460 \\
\hline KeskH 1 & 401 & $29,67 \%$ & 2041 & 578 & 3,70 & 2315 & 454 \\
\hline KeskH 2 & 516 & $8,14 \%$ & 2567 & 712 & 3,87 & 2934 & 556 \\
\hline KeskH 3 & 537 & $13,22 \%$ & 2683 & 512 & 4,22 & 2291 & 516 \\
\hline Keskmine & 318 & 17,01 & 2430 & 600,7 & 3,96 & 2513 & 509 \\
\hline
\end{tabular}

${ }^{17}$ Kõrge direktiivsusmäär võis olla tingitud ka lindistussituatsioonist - koos mängiti uut lauamängu ja õpiti selgeks selle reegleid. Kõrgesaare (2014: 170) uurimistulemuste järgi on direktiivsemad eelkõige koostööolukorrad, kus täiskasvanul on täita õpetaja ja juhendaja roll. 
Lindistatud vestlustes räägivad kõrgharidusega emad oma lastega rohkem, samas räägivad nende perede lapsed vestlustes vähem ning ka nende sõnavara on keskmiselt väiksem kui keskharidusega emade lastel (KõrgH - keskmiselt 460 lekseemi, KeskH - 509 lekseemi). Seega, kuigi kõrgharidusega vanemad on vähem direktiivsed, ei avaldu direktiivsus sõnavara kitsendava tegurina, kui analüüsida seda rühmade keskmise näitaja alusel. Küll aga avaldub seos üksikkõnelejate tasandil: mida direktiivsem on ühe rühma sees ema, seda väiksem on selle lapse sõnavara. Kõrgharidusega emade rühmas kõige rohkem direktiivseid lausungeid (12,11\%) kasutava ema (KõrgH 1) lapse sõnavara on kõrgharidusega emade rühma sees kõige väiksem (405 lekseemi). Direktiivsusmäär on haridusrühmade sees otseselt seotud lapse sõnavaraga: vähem direktiivseid lausungeid kasutanud ema (KõrgH 3) lapse sõnavara on ka suurem (475 lekseemi) ning kõige vähem direktiivse ema (KõrgH 2) lapse sõnava on selle rühma võrdluses kõige mitmekesisem (500 lekseemi). Sama seos avaldub ka keskharidusega emade rühmas, kus kõige rohkem direktiive kasutanud ema lapsel (KeskH 1) on kasinam sõnavara kui vähem direktiive kasutanud emade lastel.

Seega leidis individuaalsel tasandil kinnitust hüpotees, et lastele suunatud direktiivsus tingib väiksema sõnavara, mistõttu on direktiivsemate vanemate lastel vaesem sõnavara. Tuleb aga arvestada, et siinse artikli aluseks olev keelematerjal on piiratud ning ulatuslikumate üldistuste tegemiseks on vaja tunduvalt suuremat valimit ja rohkem keelematerjali ühe lapse kohta.

\section{Direktiivsuse laad lapse sõnavara mõjutava tegurina}

Kaudsed direktiivid on keeleliselt ja kognitiivselt keerukamad kui otsesed käsud ja keelud: kuigi kaudses direktiivis ei ole käsu adressaat alati eksplitsiitselt väljendatud, kannavad nad samal ajal ikkagi eesmärki suunata lapse tegevust. Järgnevalt on vaadeldud, kuivõrd avaldab lapse sõnavara suurusele mõju peale direktiivide üldise hulga ka nende laad ehk direktiivi intensiivsus ja otsesus-kaudsus. Tabelis 5 on esitatud lastele suunatud otseste ja kaudsete käskude hulk, kaudsete käskude osakaal kõikidest direktiividest ning lapse sõnavara mitmekesisust märkiv lekseemide arv. 
Tabel 5. Otsesed ja kaudsed käsud lastele suunatud kõnes (absoluutarvudes) ning lapse sõnavara mitmekesisus (lekseemides)

\begin{tabular}{|c|c|c|c|c|}
\hline Pere & $\begin{array}{c}\text { Otsesed } \\
\text { käsud } \\
\text { lastele } \\
\text { suunatud } \\
\text { kõnes }\end{array}$ & $\begin{array}{c}\text { Kaudsed } \\
\text { käsud } \\
\text { lastele } \\
\text { suunatud } \\
\text { kõnes }\end{array}$ & $\begin{array}{c}\text { Kaudsete } \\
\text { käskude } \\
\text { osakaal } \\
\text { kõikidest } \\
\text { direktiividest }\end{array}$ & $\begin{array}{c}\text { Lapse sõnavara } \\
\text { mitmekesisus } \\
\text { (eri lekseemide } \\
\text { arv) }\end{array}$ \\
\hline KõrgH 1 & 40 & 75 & $65,2 \%$ & 405 \\
\hline KõrgH 2 & 14 & 36 & $72 \%$ & 500 \\
\hline KõrgH 3 & 42 & 12 & $22 \%$ & 475 \\
\hline KeskH 1 & 90 & 40 & $30,8 \%$ & 454 \\
\hline KeskH 2 & 26 & 20 & $43,5 \%$ & 556 \\
\hline KeskH 3 & 44 & 33 & $42,9 \%$ & 516 \\
\hline
\end{tabular}

Tabelist on näha, et otseste või kaudsete käskude kasutus ei avalda otsest mõju lapse sõnavara suurusele. Kaudsete käskude osakaal on kõrgharidusega emade seas väga erinev, jäädes vahemikku 22-72\%. Keskharidusega emade seas on kaudsete käskude osakaal keskmiselt väiksem, ulatudes 30,8\%-st 43,5\%-ni. Kui kahe keskharidusega pere puhul on otseste käskude hulga vahe ühtlasem, siis KeskH 1 pere ema kasutab rohkesti otseseid käske (90 otsest käsku). Veel võib märgata, et keskharidusega peredes jaguneb otseste ja kaudsete käskude kasutus ühtlasemalt, samal ajal kui kahes kõrgharidusega ema peres (KõrgH 1, KõrgH 3) on kaudsete ja otseste käskude kasutamise vahe enam kui kahekordne.

Keskharidusega vanemate otseste käskude rohke kasutus kattub Helen Kõrgesaare uurimistulemustega ${ }^{18}$, mille järgi moodustavad enam kui poole kõikidest vestluses kasutatavatest direktiividest otsesed käsud (ema kõnes $60 \%$ ja isa kõnes 50\%). Kõrgesaare uuringu kohaselt suureneb kaudsete käskude hulk lapse kasvades, millest johtuvalt arutleb Kõrgesaar, et keeleliselt võimekamale lapsele saab käsku edasi anda ka kaudselt. (Kõrgesaar 2016) Siinse uurimismaterjali põhjal saab öelda, et kuigi otseste käskude hulk on mõlema haridusrühma sees suur, on kaudsete direktiivide kasutus omane pigem kõrgharidusega vanematele.

${ }^{18}$ Kõrgesaare uurimuse puhul tuleb arvestada, et andmed pärinevad vanematelt lastelt ja pikemast vaatlusperioodist (lapsi lindistati vahemikus 7-14 aastat), kuid need kajastavad vaid ühe pere vanemate keelekasutust. 
Analüüsides täpsemalt direktiivide laadi ja käsu intensiivsust, selgub, et kõrgharitud emade kõnes on eri direktiivitüübid mõnevõrra rohkem esindatud. Joonis 2 annab ülevaate eri tüüpi direktiividest emade kõnes.

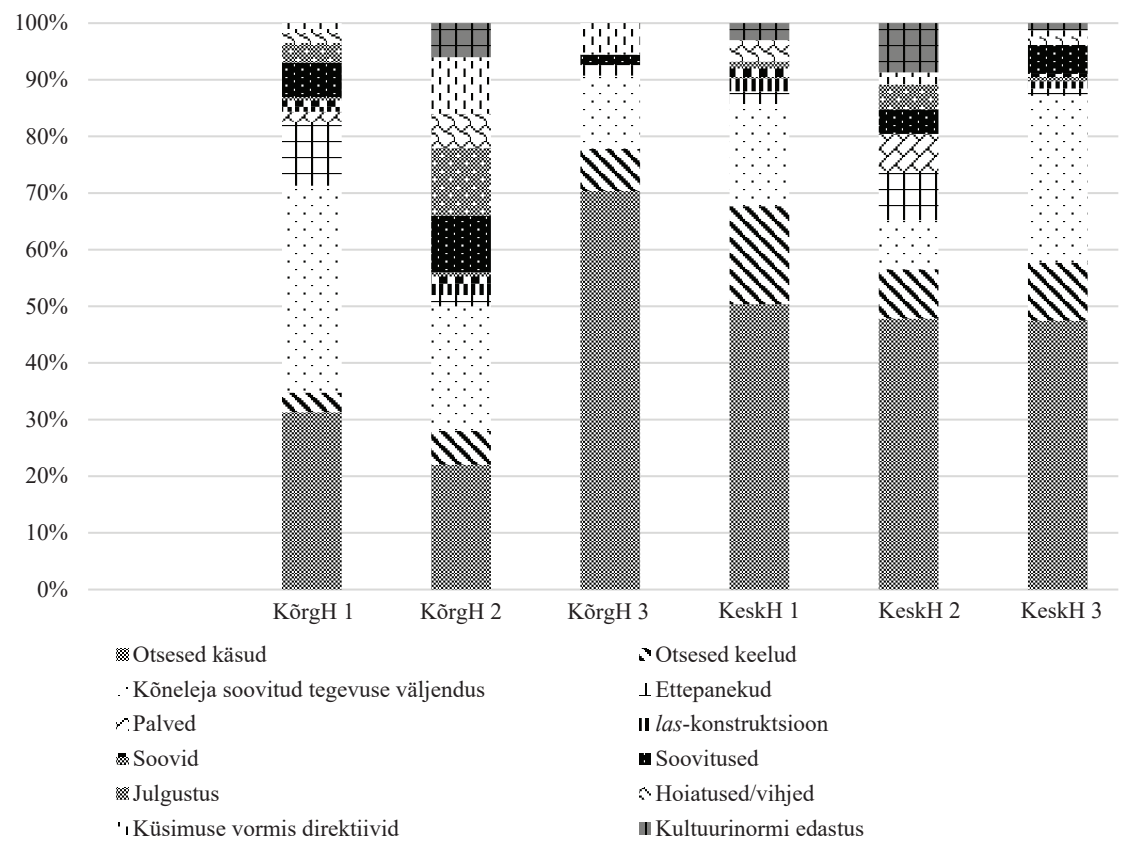

Joonis 2. Eri direktiivitüüpide osakaal ema kõnes

Kõrgharidusega vanemate kõnele on iseloomulikud julgustused, ettepanekud, küsimuste vormis direktiivid ja soovitused. Julgustuste eesmärk on küll lapse tegevuse suunamine, kuid need võivad innustada last ka verbaalselt (nt Proovi jutustada!). Julgustusi esineb kahe kõrgharidusega ema kõnes (KõrgH 1 - neljal korral, KõrgH 2 - kuuel korral). Ka kaks keskharidusega ema kasutavad julgustusi, kuid oluliselt väiksemal määral (KeskH 1 - ühel korral, KeskH 2 - kahel korral). Kõige enam julgustusi kuulnud lapsel on kõrgharidusega vanemate rühmas ühtlasi kõige rikkam sõnavara (vt tabel 5). Sama seos avaldub keskharidusega vanemate rühmas: KeskH 2 ema peres, kus laps kuuleb keskharidusega vanemate lastest enim julgustusi, kasutab ta ka kõige mitmekesisemat sõnavara. Seevastu ettepanekuid (nt Võiksime lugeda) kasutavad kõik emad, kuid 
kõige enam (13 korral) on neid KõrgH 1 ema kõnes. Küsimused (Kas sa loeksid?) esinevad kõikide kõrgharidusega emade kõnes. Soovitusi ( $\mathrm{Sa}$ võiksid lugeda) leidub kõikide kõrgharidusega emade peres vähemalt ühel korral, kõige rohkem kasutab soovitusi KõrgH 1 pere ema (seitsmel korral), teised kaks peret vastavalt viiel ja ühel korral.

Keskharidusega emade kõnet iseloomustab rohke otseste käskude ja keeldude kasutamine: lastele suunatud keelde (Ära tee!) kuulevad keskharidusega emade lapsed alati enam kui kõrgharidusega emade lapsed. Kui kõrgharidusega vanemate peres jääb keeldude kasutamine vahemikku 3-4 keeldu, siis keskharidusega vanematel varieerub see vahemikus 4-28 keeldu. Samuti on keskharidusega emade kõnele iseloomulikud kultuurinormi tähistavad direktiivid (nt Kohtunik pidi ju tasa olema; sõpradega tuleb olla nii kaua, kuni neil on tore; sõbrapäeval ju tehakse; alustatakse ikka stardist), mida esineb kõikide keskharidusega emade kõnes. Kõrgharidusega emade kõnes esineb kultuurinorme vaid KõrgH 2 peres.

Seega on kõrgharidusega vanemate kõnele iseloomulik kaudsete käskude kasutus. Kõrgharidusega emad väljendavad soovitud tegevust sagedamini ka kognitiivselt kõige keerukamate käskudega, kus ei ole imperatiivi ega muud viidet käsu adressaadile (nt Nii ja nüüd saab teha sellised kujundid; Prügikast on siin). Valimi põhjal ei saa aga kindlalt väita, et otseste ja kaudsete direktiivide hulk oleks seotud lapse sõnavara suurusega.

\section{Kokkuvõte}

Vaadeldud materjali põhjal võib öelda, et on peaaegu kolmekordne vahe, kui palju käske ja keelde kuuleb laps ühes sama pikas vestluses. Kõige enam on lapsele suunatud pooleteisetunnises vestluses 130 direktiivi, mis moodustab veidi vähem kui kolmandiku kõikidest lapsele suunatud lausungitest.

Tulemused näitasid otsest seost vanema haridustaseme ja direktiivide kasutuse vahel. Keskharidusega emade kõnes ulatub direktiivsusmäär 8,14\%-st 29,67\%-ni, kõrgharidusega emade kõnes jääb direktiivide osakaal vastavalt vahemikku $6,71-12,11 \%$. Seega on kõrgharidusega vanemate kõnes direktiivsete lausungite osakaal 8,3\% väiksem kui keskharidusega emadel, kes kasutavad vestluses keskmiselt 17,01\% direktiivseid lausungeid (kõrgharidusega emad 8,71\%). 
Haridustase on seotud ka lapsele suunatud kõne hulga ja mitmekesisusega ning lausungite hulga ja väljendi keskmise pikkusega. Kõrgharidusega ema laps kuulis vestluses üle 2000 sõne rohkem (kõrgharidusega emad suunasid lapsele keskmiselt 4482,33 sõnet, keskharidusega emad 2430,33 sõnet). Samuti oli kõrgharidusega emade keel mitmekesisem. Nii kasutasid kõrgharidusega emad vestluses keskmiselt 762,33 lekseemi, keskharidusega emad 514,33 lekseemi. Enam kui kahekordne vahe esines selles, kui palju lausungeid eelkooliealine laps pooleteisetunnises vestluses kuulis igas vestluses suunasid kõrgharidusega emad lapsele rohkem lausungeid (kõrgharidusega emad keskmiselt 746,67, keskharidusega emad 484,67 lausungit). Samuti olid kõrgharidusega emade väljendid igas vestluses umbes ühe sõne võrra pikemad.

Direktiivne kõne eristus lastele suunatud kõne hulga, mitmekesisuse ning lausungite hulga ja väljendite keskmise pikkuse poolest. Kuigi kõikide perede lõikes ei esinenud negatiivset seost ema kõne direktiivsusmäära ja kõne hulga vahel, oli valimis kõige enam käske ja keelde lapsele suunanud ema keel kõige väiksema kõne hulgaga (sõnedes). Samuti oli kõige suurema direktiivide osakaaluga ema lapse sõnavara ligi kaks korda väiksem. Seega tingis kõrge direktiivsusmäär väiksema hulga lühemaid lausungeid. Seevastu kõige vähem direktiive kasutanud ema lausungid olid kõige pikemad (6,11 sõnet).

Hüpotees lapsele suunatud direktiivsuse kui sõnavara pärssiva teguri kohta leidis kinnitust mõlema rühma sees üksikkõnelejate tasandil - mida direktiivsem on ema, seda kasinam on lapse sõnavara. Rühmiti seos direktiivide hulga ja sõnavara mitmekesisuse vahel keskmise näitajana ei avaldunud, sest kuigi kõrgharidusega vanemad olid vähem direktiivsed, kasutasid nende lapsed kasinamat sõnavara kui keskharidusega emade lapsed. Siinjuures tuleb arvestada, et siinse uurimuse aluseks olev keelematerjal on liiga väike, et teha laiemaid üldistusi.

Kinnitust ei leidnud hüpotees, et lapse sõnavara suurusele avaldab mõju direktiivide laad ehk direktiivi intensiivsus otsesuse-kaudsuse näol. Küll aga leidis kinnitust hüpotees, et kõrgharidusega emade kõnet iseloomustasid pigem kognitiivselt keerukamad kaudsed käsud. Seejuures oli kaudsete käskude osakaal kõrgharidusega emade seas väga erinev, varieerudes vahemikus $22-72 \%$. Keskharidusega peredes jagunes otseste ja kaudsete käskude kasutamine ühtlasemalt (kaudsete käskude osakaal ulatus 30,8\%-st 43,5\%-ni). 
Kõrgharitud emade kõnes esines enam ka eri tüüpi direktiive ning nende hulgast esildusid julgustused, ettepanekud, küsimuste vormis direktiivid ja soovitused. Lastele suunatud julgustuste puhul avaldus mõlemas haridusrühmas seos julgustuste hulga ja sõnavara mitmekesisuse vahel: enam julgustusi kuulnud lastel on ka kõige rikkam sõnavara. See seos näitab, et teatud tüüpi direktiivide korral võib direktiivsus sõnavara arendada, mistõttu on oluline analüüsida eri tüüpi direktiive üksikasjalikumalt.

Edasistes hoidjakeele direktiivide uurimustes oleks ulatuslikumate üldistuste tegemiseks kindlasti vajalik suurem valim. Siinse uurimuse tarbeks koostatud korpus, mis põhineb ühtsetel sotsiolingvistilistel kriteeriumitel, annab võimaluse võrrelda uusi andmeid juba olemas olevatega.

\section{Kirjandus}

Aikhenvald, Alexandra 2010. Imperatives and Commands. Oxford: Oxford University Press.

Akhtar jt 1991 = Nameera Akhtar, Frances Dunham, Philip J. Dunham. Directive interactions and early vocabulary development: the role of joint attentional focus. - Journal of Child Language 18 (1), 41-49.

Andersen, Elaine S. 1990. Speaking with style: the sociolinguistic skills of children. London: Routledge.

Argus, Reili 2008. Eesti keele muutemorfoloogia omandamine. Analüütiline ülevaade. (= Tallinna Ülikooli humanitaarteaduste dissertatsioonid 19.) Tallinn: Tallinna Ülikooli Kirjastus.

Argus, Reili, ilmumas. Acquisition of directives in Estonian. - Acquisition of requests. Eds. Maria Voeikova, Ursula Stephany, Ayhan Aksu-Koç. Mouton de Gruyter.

Barnes jt 1983 = Sally Barnes, Mary Gutfreund, David Satterly, Gordon Wells. Characteristics of adult speech which predict children's language development. - Journal of Child Language 10 (1), 65-84. https://doi. org/10.1017/S0305000900005146.

Bates, Elizabeth 1976. Language and Context - the Acquisition of Pragmatics. New York: Academic Press.

Bornstein jt 1999 = Marc H. Bornstein, Catherine S. Tamis-LeMonda, O. Maurice Haynes. First words in the second year: Continuity, stability, and models of concurrent and predictive correspondence in vocabulary and verbal responsiveness across age and context. - Infant Behavior \& Development 22 (1), 65-85. https://doi.org/10.1016/S0163-6383(99)80006-X.

Bornstein jt 2003 = Marc H. Bornstein, Chun-Shin Hahn, Joan T. D. Suwalsky, O. Maurice Haynes. Socioeconomic status, parenting, and child devel- 
opment: the Hollingshead four-factor index of social status and the socioeconomic index of occupations. - Socioeconomic Status, Parenting, and Child Development. Monographs in Parenting Series. Eds. Marc H. Bornstein, Robert H. Bradley. Mahwah: Lawrence Erlbaum Associates Publishers, 29-82.

Chejnová, Pavla 2015. Development of directives in child language: a case study of Czech. - Topics in Linguistics 15 (1). https://doi.org/10.2478/ topling-2015-0002.

Clark, Eve Vivienne 2003. First Language Acquisition. Cambridge: Cambridge University Press.

Craven, Alexandra, Jonathan Potter 2010. Directives: entitlement and contingency in action. - Discourse Studies 12 (4), 419-442. https://doi. org/10.1177/1461445610370126.

Curl, Traci S., Paul Drew 2008. Contingency and action: a comparison of two forms of requesting. - Research on Language and Social Interaction 41 (2), 129-53. https://doi.org/10.1080/08351810802028613.

EKG II = Mati Erelt, Reet Kasik, Helle Metslang, Henno Rajandi, Kristiina Ross, Henn Saari, Kaja Tael, Silvi Vare 1993. Eesti keele grammatika II. Süntaks. Lisa: Kiri. Peatoim. Mati Erelt, toim. Tiiu Erelt, Henn Saari, Ülle Viks. Tallinn: Eesti Teaduste Akadeemia Keele ja Kirjanduse Instituut.

Ellis, Rod, Gordon Wells 1980. Enabling factors in adult-child discourse. - First Language 1 (1), 46-62. https://doi.org/10.1177/014272378000100104.

Erelt, Mati, Helle Metslang (toim.) 2017 = Eesti keele süntaks. (Eesti keele varamu III.) Tartu: Tartu Ülikooli Kirjastus.

Ervin-Tripp, Susan 1976. "Is Sybil There?" The structure of some American English directives. - Language in Society 5 (1), 25-66. http://dx.doi. org/10.1017/S0047404500006849.

Frank Masur, Elise, Margaret Turner 2001. Stability and consistency in mothers' and infants' interactive styles. - Merrill-Palmer Quarterly 47 (1), 100-120.

Goldfield, Beverly A., J. Steven Reznick 1990. Early lexical acquisition: rate, content, and the vocabulary spurt. - Journal of Child Language 17 (1), 171-183. http://dx.doi.org/10.1017/S0305000900013167.

Grosse jt 2010 = Gerlind Grosse, Henrike Moll, Michael Tomasello. 21-Montholds understand the cooperative logic of requests. - Journal of Pragmatics 42 (12), 3377-3383. https://doi.org/10.1016/j.pragma.2010.05.005.

Harris jt 1986 = Margaret Harris, David Jones, Susan Brooks, Julia Grant. Relations between the non-verbal context of maternal speech and rate of language development. - British Journal of Developmental Psychology 4 (3), 261-269. https://doi.org/10.1111/j.2044-835X.1986.tb01017.x. 
Hart, Betty, Todd R. Risley 2003. The early catastrophe: the 30 million word gap by age 3. - American Educator, Spring, 4-9. http://www.aft.org// sites/default/files/periodicals/TheEarlyCatastrophe.pdf (08.05.2019).

Hill, Elizabeth 2009. Do mothers and fathers differ in their speech styles when speaking to their children? Are there speaker gender effects on parents' language behaviour? - Innervate: Leading Undergraduate Work in English Studies 2, 163-182.

Hoff, Erika 2003. The specificity of environmental influence: socioeconomic status affects early vocabulary development via maternal speech. Child Development 74 (5),1368-1378. http://dx.doi.org/10.1111/14678624.00612.

Hoff, Erika 2006. How social contexts support and shape language development. - Developmental Review 26 (1), 55-88. https://doi.org/10.1016/j. dr.2005.11.002.

Hoff-Ginsberg, Erika 1998. The relation of birth order and socioeconomic status to children's language experience and language development. Applied Psycholinguistics 19 (4), 603-629. https://doi.org/10.1017/ S0142716400010389.

Huls, Erica, Carel van Wijk 2012. The development of a directive repertoire in context: A case study of a Dutch speaking young child. - Journal of Pragmatics 44 (1), 83-103.

Huttenloher jt 2010 = Janellen Huttenlocher, Heidi Waterfall, Marina Vasilyeva, Jack Vevea, Larry V. Hedges. Sources of variability in children's language growth. - Cognitive Psychology 61 (4), 343-365. doi: 10.1016/j. cogpsych.2010.08.002.

Im-Bolter jt 2013 = Nancie Im-Bolter, Zohreh Yaghoub Zadeh, Daphne Ling. Early parenting beliefs and academic achievement: the mediating role of language. - Early Child Development and Care 183 (12), 1811-1826. http://dx.doi.org/10.1080/03004430.2012.755964.

Kaljumäe, Kai 2010. Eesti laste kõne arengust 16-30 kuu vanuste laste näitel. Magistritöö. Tartu: Tartu Ülikool.

Kõrgesaar, Helen 2014. Eesti isade-emade hoidjakeel: kes küsib, kes käsutab, kes räägib rohkem? - Uurimusi keele omandamisest, õppimisest ja korpustest. Toim. Krista Kerge. (= Tallinna Ülikooli eesti keele ja kultuuri instituudi toimetised 16.) Tallinn: Tallinna Ülikool, 59-82.

Kõrgesaar, Helen 2015. Direktiivsed kõneaktid ning nende kasutamise dünaamika isa ja ema kõnes: juhtumiuuring. - Eesti Rakenduslingvistika Ühingu aastaraamat 11 (2015). Toim. Helle Metslang, Margit Langemets, MariaMaren Sepper. Tallinn: Eesti Rakenduslingvistika Ühing, 159-175.

Kõrgesaar, Helen 2016. Eesti hoidjakeele pragmaatilised erijooned ja dünaamika ning mõju lapse keele arengule. (= Tallinna Ülikooli humanitaarteaduste dissertatsioonid 27.) Tallinn: Tallinna Ülikool. 
Kütt, Andra 2015. Eesti keelt emakeelena omandavate laste (vanuses 6-7 eluaastat) sõnavara sotsiolingvistiline uurimus. Magistritöö. Tallinn: Tallinna Ülikool.

Kütt, Andra, Argus, Reili 2017. Eesti keelt emakeelena omandavate kuueaastaste laste sõnavara seosed emade sõnavaraga. - Emakeele Seltsi aastaraamat 63 (2017). Peatoim. Mati Erelt. Tallinn: Teaduste Akadeemia Kirjastus, 77-102. http://dx.doi.org/10.3176/esa63.03.

Laan, Heli 2006. Lapse sõnavara suurus ja seda mõjutavad tegurid. Tartu: Tartu Ülikool.

Laanesoo, Kirsi 2018. Polüfunktsionaalsed küsilaused eesti argivestluses. (= Dissertationes linguisticae Universitatis Tartuensis 33.) Tartu: Tartu Ülikooli Kirjastus.

Leech jt 2013 = Kathryn A. Leech, Virginia S. Salo, Meredith L. Rowe, Natasha J. Cabrera. Father input and child vocabulary development: The importance of $w h$-questions and clarification requests. - Seminars in Speech and Language 34 (4), 249-259. doi: 10.1055/s-0033-1353445.

Leping, Kristjan-Olari 2005. Inimkapitali ja palga seosed Eestis ning nende dünaamika. - Majandusteadus ja haridus Eestis. Toim. Diana Eerma. Tartu: Tartu Ülikooli Kirjastus, 15-43.

MacWhinney, Brian 1991. The CHILDES project: Tools for Analyzing Talk. Hillsdale: Lawrence Erlbaum Associates. http://dx.doi.org/10. 1177/026565909200800211.

MacWhinney, Brian 2000. The CHILDES project. Tools for analyzing talk. 3rd ed. Mahwah: Lawrence Erlbaum Associates.

Metslang, Helle 2004. Imperative and related matters in everyday Estonian. Linguistica Uralica 4, 243-256.

Nelson, Katherine 1973. Structure and strategy in learning to talk. - Monographs of the Society for Research in Child Development 38 (1-2), 1-135. http:// dx.doi.org/10.2307/1165788.

Okugo, Chierika 2015. Caregiver speech to infants in Senegal: a descriptive study. - Stanford: Journal of Public Health 20. https://web.stanford.edu/ group/sjph/cgi-bin/sjphsite/caregiver-speech-to-infants-in-senegal-adescriptive-study/ (09.05.2019).

Paavola-Ruotsalainen jt 2017 = Leila Paavola-Ruotsalainen, Jaana Lehtosaari, Josefina Palomäki, Immi Tervo. Maternal verbal responsiveness and directiveness: consistency, stability, and relations to child early linguistic development. - Journal of Child Language 45 (2), 319-339. https://doi. org/10.1017/S030500091700023X.

Pajusalu, Karl, Renate Pajusalu 2004. The conditional in everyday Estonian: It's form and functions. - Linguistica Uralica 40 (4), 257-269.

Pine, Juliane Mark 1992. How referential are 'referential' children? Relationships between maternal-report and observational measures of vocabulary 
composition and usage. - Journal of Child Language 19 (1), 75-86. https://doi.org/10.1017/S0305000900013635.

Prizant, Barry, Elaine C. Meyer 1993. Socioemotional aspects of language and social-communication disorders in young children and their families. American Journal of Speech-Language Pathology 2 (3), 56-71. https:// doi.org/10.1044/1058-0360.0203.56.

Rääbis, Andriela 2012. Direktiivisekventsid isa ja tütre suhtluses: juhtumianalüüs. - Eesti Rakenduslingvistika Ühingu aastaraamat 8 (2012). Toim. Helle Metslang, Margit Langemets, Maria-Maren Sepper. Tallinn: Eesti Rakenduslingvistika Ühing, 213-230. http://dx.doi.org/10.5128/ ERYa8.14.

Rowe, Meredith L. 2008. Child-directed speech: relation to socioeconomic status, knowledge of child development and child vocabulary skill. Journal of Child Language 35 (1), 185-205. https://doi.org/10.1017/ S0305000907008343.

Rowe, Meredith L. 2012. A longitudinal investigation of the role of quantity and quality of child-directed speech in vocabulary development. Child Development 83 (5), 1762-1774. https://doi.org/10.1111/j.14678624.2012.01805.x.

Searle, John 1979. Expression and Meaning: Studies in the Theory of Speech Acts. Cambridge: Cambridge University Press. http://dx.doi.org/10.1017/ CBO9780511609213.

Siska, Teele 2013. Imperatiivi kasutusest ühe lapse kõnearengu varasel perioodil. Bakaleureusetöö. Tartu: Tartu Ülikool.

Slančová, Daniela 2008. Štúdie o dětskej reči. Prešov: Filozofickáfakulta Prešovskej univerzity v Prešove.

Stephany jt 2013 = Ursula Stephany, Ayhan Aksu-Koç, Maria D. Voeikova. The category of modality: A crosslinguistic study of its development. Ettekanne rahvusvahelisel pre- ja protomorfoloogia projekti aastakonverentsil Viinis (21.-23.02.2013).

Stephany, Ursula, Maria D. Voeikova 2015. Requests, their meanings and aspectual forms in early Greek and Russian child language. - Journal of Greek Linguistics 15 (1), 66-90. https://doi.org/10.1163/15699846-01501002.

Tammemäe, Tiiu 2008. Kahe- ja kolmeaastaste eesti laste kõne arengu tase Reynelli ja HYKS testi põhjal ning selle seosed koduse kasvukeskkonna teguritega. (= Tallinna Ülikooli sotsiaalteaduste dissertatsioonid.) Tallinn: Tallinna Ülikooli Kirjastus.

Teemets, Helena 2012. Direktiivid eesti keele argivestlustes. Magistritöö. Tartu: Tartu Ülikool.

Tomasello, Michael 2003. Constructing a Language. A Usage-based Theory of Language Acquisition. Cambridge, London: Harvard University Press. 
Tomasello, Michael 2005. Constructing a Language: A Usage-based Theory of Language Acquisition. Cambridge: Harvard University Press.

Tomasello, Michael 2010. Origins of Human Communication. Cambridge: MIT Press.

Tomasello Michael, Michael Jeffrey Farrar 1986. Joint attention and early language. - Child Development 57 (6), 1454-1463. http://dx.doi. org/10.2307/1130423.

Tomasello, Michael, Jody Todd 1983. Joint attention and lexical acquisition style. - First Language 4 (12), 197-212. https://doi.org/10.1177 $\% 2 \mathrm{~F} 014272378300401202$.

Tulviste, Tiia 2001. Can variation in mother-child interaction be explained by context and collectivistic attitudes? - Applied Psycholinguistics 22 (4), 541-553. https://doi.org/10.1017/S0142716401004039.

Tulviste, Tiia 2003. Mothers'conversational styles across cultures. The case of Estonia, Finland, Sweden and the U.S. - Proceedings of the IACCP XVIth Congress, Yogyakarta, Indoneesia, 15.-19. juuli 2002.

Tulviste, Tiia 2007. Variation in vocabulary development among Estonian children as a function of child's gender, birth order, child-care, and parental education. - Proceedings from the First European Network Meeting on the Communicative Development Inventories. Ed. M. Eriksson. Gävle: University of Gävle, 16-21.

Tulviste jt 2003 = Tiia Tulviste, Luule Mizera, Boel De Geer, Marja-Terttu Tryggvason. A comparison of Estonian, Swedish, and Finnish mothers' controlling attitudes and behaviour. - International Journal of Psychology 38 (1), 46-53. https://doi.org/10.1080/00207590244000278.

Tulviste jt 2004 = Tiia Tulviste, Luule Mizera, Boel De Geer. Expressing communicative intents in Estonian, Finnish, and Swedish mother-adolescent interactions. - Journal of Child Language 31 (4), 801-819. https://doi. org/10.1017/S0305000904006488.

Urm, Ada 2012. Individuaalsete erinevuste stabiilsus eesti laste sõnavara arengus. Magistritöö. Tartu: Tartu Ülikool.

Urm, Ada, Tiia Tulviste 2016. Sources of individual variation in Estonian toddlers' expressive vocabulary. - First Language 36 (6), 580-600. https:// doi.org/10.1177\%2F0142723716673951.

Vihman, Virve-Anneli 2018. Pilk laste keeleomandamisele: teoreetilistest alustest ja kvantitatiivsetest lähenemistest. - Keel ja Kirjandus 8/9, 622-642.

Willms, Douglas J. 2003. Ten Hypotheses about Socioeconomic Gradients and Community Differences in Children's Developmental Outcomes. Applied Research Branch, Strategic Policy, Human Resources Development Canada, Final Report. 


\title{
Directive speech acts in child directed speech, the connection between the education level of the parent and the child's vocabulary
}

\author{
ANDRA KÜTT
}

Directive speech acts are a natural part of speech which help parents to direct or guide the child's activities as well as to teach them. The aim of this article is to describe 1) the level of directness-indirectness used in spontaneous child-directed speech, 2) whether and how the frequency and type (i.e. the cognitive complexity) of directive speech acts are related to the parent's education level and 3) whether directness is a hindering factor for the child's vocabulary. The data used in the research includes 9 hours of spontaneous speech recordings. The speech of a total of six families have been analysed: three families where the mother has higher education and three with mothers who have secondary education.

The number of child-directed directive speech acts varied: in 1.5 hours of dialogue, from 46 to 130 speech acts were found. Mothers with higher education produced, on average, half as many directive utterances as mothers with secondary education. It was characteristic for parents with higher education to use indirect commands in their speech. However, the portion of indirect commands that mothers with higher education used varied greatly, from 22 to 72 per cent. The distribution of direct and indirect commands was more equal among families with secondary education (the portion of indirect commands ranged from 30.8 to 43.5 per cent). Parents with higher education also showed a greater variety in the types of directive speech acts. Thus, the occurrence of speech acts such as encouragements, proposals and questions, as well as recommendations could be noted.

It is characteristic for mothers with secondary education to frequently use commands and prohibitions: children whose parents only have secondary education will always hear more child-directed prohibitions (Don't do it!) than the children whose parents also have a higher education. It is also characteristic for mothers with secondary education to use more directive speech acts referring to cultural norms (e.g. The judge was supposed to be quiet).

The results of the study indicate that directness is connected on an individual level with children's vocabulary - the more directive speech acts the parent produced, the smaller the child's vocabulary was. There was, however, no direct 
connection between the frequency and variance in the type of directive speech acts and the variety of the child's vocabulary.

Keywords: first language acquisition, child directed speech, sociolinguistics, directives, vocabulary

Andra Kütt

humanitaarteaduste instituut

Tallinna Ülikool

Narva mnt 25

10120 Tallinn

andra.kutt@tlu.ee 